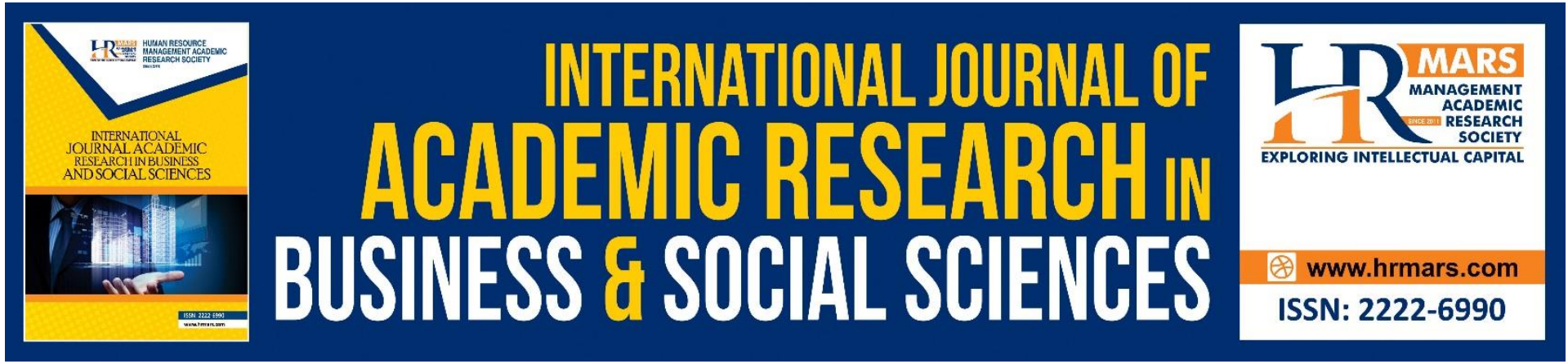

\title{
Maqasid Al-Shariah Theory: A Comparative Analysis Between The Thoughts Of Al-Shatibi And 'Izz Al-Din Ibn 'Abd Al-Salam
}

Marina Abu Bakar \& Ahmad Khilmy Abdul Rahim

To Link this Article: http://dx.doi.org/10.6007/IJARBSS/v11-i8/10683

DOI:10.6007/IJARBSS/v11-i8/10683

Received: 07 June 2021, Revised: 01 July 2021, Accepted: 22 July 2021

Published Online: 08 August 2021

In-Text Citation: (Bakar \& Rahim, 2021)

To Cite this Article: Bakar, M. A., \& Rahim, A. K. A. (2021). Maqasid Al-Shariah Theory: A Comparative Analysis Between The Thoughts Of Al-Shatibi And 'Izz Al-Din Ibn 'Abd Al-Salam. International Journal of Academic Research in Business and Social Sciences, 11(8), 180-193.

Copyright: (c) 2021 The Author(s)

Published by Human Resource Management Academic Research Society (www.hrmars.com)

This article is published under the Creative Commons Attribution (CC BY 4.0) license. Anyone may reproduce, distribute, translate and create derivative works of this article (for both commercial and non-commercial purposes), subject to full attribution to the original publication and authors. The full terms of this license may be seen at: http://creativecommons.org/licences/by/4.0/legalcode

Vol. 11, No. 8, 2021, Pg. 180 - 193

Full Terms \& Conditions of access and use can be found at http://hrmars.com/index.php/pages/detail/publication-ethics 


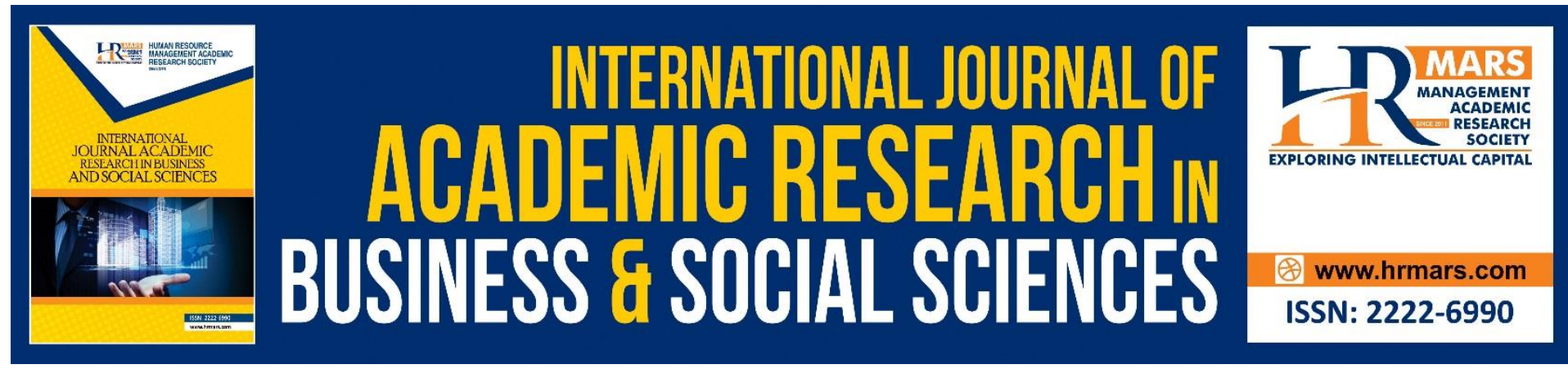

\title{
Maqasid Al-Shariah Theory: A Comparative Analysis Between The Thoughts Of Al-Shatibi And 'Izz Al-Din Ibn 'Abd Al-Salam
}

\author{
Marina Abu Bakar ${ }^{1} \&$ Ahmad Khilmy Abdul Rahim² \\ ${ }^{1}$ Kulliyyah of Shariah and Law, Universiti Islam Antarabangsa Sultan Abdul Halim Mu'adzam \\ Shah (UniSHAMS), 09300, Kuala Ketil, Kedah, 'Islamic Business School, College of Business, \\ Universiti Utara Malaysia (UUM), 06010, Sintok, Kedah. \\ Email: marinaabubakar@unishams.edu.my
}

\begin{abstract}
Maqasid al-Shariah is a unique discipline of Islamic knowledge in Islamic law. Understanding the maqasid al-Shariah is very important in understanding the true objectives of Islamic texts more comprehensively and accurately. Al-Shatibi and 'Izz al-Din ibn 'Abd al-Salam are among the leading figures and important references for contemporary Islamic law researchers in the field of maqasid al-Shariah. This article aims to analyze the comparison of thoughts between al-Shatibi and 'Izz al-Din ibn' Abd al-Salam on the theory of maqasid al-Shariah. This is a qualitative research using library methods where data were obtained from classical and contemporary sources of Islamic law. The data were then analyzed using comparative methods. The results of the research found that although there are similarities in their thoughts, but the form of thinking between these two Islamic figures is still different. AlShatibi has divided the maqasid al-Shariah into two parts, namely the maqasid al-Shariah and the maqasid al-Mukallaf. Whereas, 'Izz al-Din ibn 'Abd al-Salam, on the other hand, discusses the theory of maslahah and mafsadah, which is a twin concept that refers to the maqasid alShariah. These two Islamic figures emphasize the aspects of maslahah and mafsadah and consider its concept as the basis for the existence of maqasid al-Shariah. The two figures have also made a division in al-Daruriyyat al-Khams (five interests). In discussing this problem, both figures have listed the five things without giving a sequence. Al-Shatibi didn't add any element in the discussion of al-Daruriyyat al-Khams, while 'Izz al-Din ibn 'Abd al-Salam added the element of maintaining dignity $(a l-' I r d)$. Nonetheless, both of them are using al-Tajribah (experiment) to identify maqasid al-Shariah. However, al-Shatibi didn't mentioned about the inductive (istiqra') method in identifying maqasid al-Shariah and prioritize the text (nas) over the intellect ('aql) in worldly and hereafter matters. This is contrasting with 'Izz al-Din ibn 'Abd al-Salam as he used intellect ('aql) to identify the maqasid al-Shariah in worldly matters, while the matters related to hereafter according to him can be determined through the text (nas) of Islamic law. This research is likely to contribute towards a new insight to the discipline of usul al-Fiqh and theory of maqasid al-Shariah for contemporary applications.
\end{abstract}

Keywords: Maqasid al-Shariah, Al-Shatibi, 'Izz al-Din Ibn 'Abd al-Salam. 


\section{Introduction}

Maqasid al-Shariah is a combination of two words namely; maqasid and al-Shariah. The word maqasid is a plural word from maqsud, maqsid or qusud which comes from the verb qasada and yaqsudu which has various meanings, namely towards a direction, purpose, middle, fair, not exceeding boundaries and a straight path (Mawardi, 2010). Shariah in terms of terminology is al-Nusus al-Muqaddasah (holy texts) from the Quran and the revealed Sunnah (mutawatir), which has not been mixed with human thought. Shariah includes faith, worship, and morality (Bakri, 1996). Maqasid al-Shariah terminologically carries the meaning of values and meanings that are made the purpose and want to be realized by Allah SWT behind Shariah and law, which is researched by the Muslim scholars (mujtahid) from the Shariah texts (Auda, 2007). Al-Shatibi was the only scholar who successfully compiled and renewed the discipline of maqasid al-Shariah so that the knowledge can be better understood and deepened by later generations. Similarly, 'Izz al-Din Ibn 'Abd al-Salam, his ideas have always been a reference in the field of maqasid al-shariah. There is no denying that the contribution of these two figures in the discipline of maqasid al-Shariah is a great contribution to contemporary researchers today. In fact, the ideas and thoughts of both figures on the theory of maqasid al-Shariah became the main basis and reference for Shariah (Islamic law) researchers. In this article, a comparative analysis is made between the thinking of al-Shatibi and 'Izz al-Din Ibn 'Abd alSalam by looking at the extent of similarities and differences expressed by both famous figures about the theory of maqasid al-Shariah.

\section{Background of Al-Shatibi and 'Izz al-Din Ibn 'Abd al-Salam}

The full name of al-Shatibi is Abu Ishaq Ibrahim ibn Musa ibn Muhammad al-Gharnathi alLakhmi. He was given the title of al-Shatibi and was descended from al-Lakhmi because he was descended from the Arabs of the Lakhm tribe (al-Din Zarkali, 1987; al-Raysuni, 1992; Abu al-Ajfan, 1985 \& al-'Ubaydi, 1992). He was born in a city known as Granada. His family comes from the city of Shatibah (Sativa). The most accurate opinion says that al-Shatibi was born before the year $720 \mathrm{AH}$ (Majdi 'Asyur, 2002). He adhered to the Maliki sect and was a diligent learner from an early age. He began to study by deepening the Arabic language. Later, he deepened his knowledge of Shariah, Quran, Sunnah, astronomy, logic (mantiq), debate and even literature (Mas'ud, 1995). Among his teachers were Abu 'Abd Allah Muhammad ibn alFakhkhar al-Ilbiri (expert in Arabic grammar and al-Qira'at al-Sab'ah), Abu Ja'afar Ahmad ibn Adam al-Shaqrawi (scholar of knowledge) fiqh, faraid and Arabic grammar), Abu 'Abd Allah Muhammad ibn Muhammad al-Maqarri (famous for the title al-Maqarri al-Kabir, an expert in the science of Qawa'id fiqhiyyah), Abu al-Qasim ibn Ahmad al-Syarif al-Hasani al-Sabti (expert in oratory, rhetoric, author and judge in Granada), Abu 'Ali Mansur ibn 'Ali al-Zawawi (expert in debate and scholar), Abu 'Abd Allah ibn Ahmad al-Syarif al-Tilimsani (expert and reference in the Maliki school), Shams al-Din Abu 'Abd Allah Muhammad ibn Ahmad ibn Marzuq alKhatib al-Tilimsani (expert in usul al-Fiqh, figh, philosophy and tasawwuf), Abu Faraj ibn Ahmad ibn Lubb al-Taghlibi (great scholar, mufti and preacher at the University of Granada mosque), Abu 'Abd Allah Muhammad ibn Abu Hajjaj al-Yahbusi (expert in the field of Arabic grammar (nahw and sarf) and Arabic language) and Abu 'Abd Allah Muhammad ibn 'Ali alBalnisi al-Awsi (expert in the field of tafsir) (Baba, 1989, Adam 'Ali, 1998; \& Subuie, 1999). Among his famous disciples were al-Qadi Abu Yahya ibn 'Asim, al-Qadi Abu Bakr ibn 'Asim and Syakh Abu 'Abd Allah ('Ali, 1998, Subuie, 1999 \& al-Ajfan, 1985). His published works are AlMuwafaqat fi Usul al-Shariah, Al-I'tisam, Al-Ifadat wal al-Insyadat and Fatwa of Imam al- 
Shatibi (Bakri, 1996 \& al- 'Ubaydi, 1992). Some historians say that he died on Tuesday, Sha'ban 790 Hijrah / 1388M (Qahalah, 1998).

'Abd al-'Aziz ibn 'Abd al-Salam ibn Abi Qasim ibn Muhammad al-Salami or also known as 'Izz al-Din was a scholar from Morocco, born in Damascus, died in Egypt and a follower of the Shafi'e school (Qahalah et al., 1981). His disciple named Ibn Daqiq al-'Ayd called him Sultan al-'Ulama because of his determination to uphold the truth and prevent evil against the sultan and king at that time (Abd al-Wahhab Taqi al-Din al-Subki). Historians have agreed that the birth of 'Izz al-Din ibn 'Abd al-Salam in Damascus and differ on the date of his birth either in 587 or $588 \mathrm{H}$. This is because his date of birth is not known accurately (Berkani, 1999). He spent 30 years to gain knowledge until he mastered a field of knowledge perfectly. He studied hadith and tafsir, figh, usul al-Fiqh and Arabic language in the city of Damascus. He also studied in the city of Baghdad in $597 \mathrm{H}$. He was in the city of Baghdad for a few months, then returned to Damascus after seeking knowledge from the scholars in the city of Baghdad. In $639 \mathrm{H}$, he migrated to Egypt to deepen his religious knowledge. Among his teachers were 'Abd al-Latif ibn Syaykh Syuyukh (expert in the field of hadith), Barakat ibn Ibrahim al-Khusya'i (expert in Sufism), Qasim ibn 'Asakir (expert in the field of hadith), Jamal al-Din al-Harastani (expert in the field of fiqh and hadith), Fakhr al-Din ibn 'Asakir (expert in the field of fiqh), Saif al-Din al-'Amidi (expert in usul al-Fiqh) and others (Berkani, 1999; Syalbi, 1992). Among his students were Sharif al-Din al-Tilmasani, Abu Makrim ibn Masdi al-Mahlabi, Shihab al-Din Abu Samah, Jalal al-Din Dashnawi, Ahmad Idris al-Qarafi, Taj al-Din al-Farkahi, Ibn Sayyid al-Qufti and others (Berkani, 1999 \& 'Ali al-Jambatali, Hasan, 1971). Among his works were Risalah fi 'Ilmi Tawhid, Bayan Ahwal al-Nas Yawm al-Qiyamah, Qawa'id al-Ahkam fi Masalih al-Anam, Shajarah al-Ma'arif wa al-Ahwal wa Salih al-Aqwal wa al-Akmal and others (Berkani, 1999). 'Izz al-Din ibn 'Abd al-Salam died on 9 Jamadil Awal in $660 \mathrm{H}$. He was buried in the Qurafah on the hill of Muqattam. His death and burial were witnessed by the King of Egypt and Syria as well as the key leaders of each state (al-Subki \& Ismail, 1945). Table 1.1 is the background of al-Shatibi and 'Izz Al-Din ibn 'Abd Al-Salam:

\begin{tabular}{|c|c|}
\hline Al-Shatibi (790 H) & 'Izz Al-Din Ibn ‘Abd Al-Salam (660 H) \\
\hline $\begin{array}{l}\text { - A scholar from Granada, Andalusia } \\
\text { (Spain). }\end{array}$ & - A scholar from Damascus, Syria. \\
\hline $\begin{array}{l}\text { - Always engaged in knowledge } \\
\text { activities. }\end{array}$ & $\begin{array}{l}\text { - Holds important positions like Qadi } \\
\text { and Mufti. }\end{array}$ \\
\hline $\begin{array}{l}\text { - Was under the rule of four Sultans of } \\
\text { Bani Ahmar. }\end{array}$ & $\begin{array}{l}\text { - Was under the rule of Dawlah } \\
\text { 'Abasiyyah and Mamalik. }\end{array}$ \\
\hline - Follower of Maliki school. & - A follower of Shafi'e school. \\
\hline - Tends to follow the Usuli approach. & $\begin{array}{l}\text { - Tends to follow the Sufism approach } \\
\text { (tasawwuf) }\end{array}$ \\
\hline - Book: Al-Muwafaqat & $\begin{array}{l}\text { - Book: Qawaid al-Ahkam fi Masalih } \\
\text { al-Anam }\end{array}$ \\
\hline
\end{tabular}

Table 1.1: The Background of Al-Shatibi and 'Izz Al-Din ibn 'Abd Al-Salam

\section{The Theory of Maqasid Al-Shariah According to Al-Shatibi}

Al-Shatibi was one of the earliest scholars to write about maqasid al-Shariah in detail and systematically. In fact, al-Shatibi considers that maqasid al-Shariah is goodness (al-Syatibi \& 'Asyur, 2002). Therefore, through his book, al-Muwafaqat fi Usul al-Syari'ah, he has divided the maqasid al-Shariah into two main parts, namely; maqasid al-Shari' and maqasid al- 
Mukallaf. Maqasid al-Shariah is the purpose or objective of Shariah determined by Allah SWT in prescribing a law. Its purpose is to bring good and avoid damage in this world and the hereafter. This maqasid al-Shari' was then divided into four parts, namely; the purpose of Allah creating something based on Shariah, the purpose of Allah introducing Shariah to be understood, the purpose of Allah making Shariah to be practiced and the purpose of Allah to place mukallaf under Shariah (al-Shatibi, 1996; al-Raysuni, 1991).

The first aspect, which is the purpose of God presenting Shariah is the most important aspect because it is related to the fact of the existence of shariah itself. The real purpose of the introduction of Shariah for human beings is to realize the benefits for human beings. In realizing the benefits for human beings, there are five elements that need to be taken care of, namely; religion, soul, lineage, property and intellect (al-Syatibi, 2006). Al-Shatibi said that the purpose of Shariah created by Allah is to realize the maqasid al-Shariah to human beings; that is, giving good (maslahah) and rejecting bad (mafsadah). Maqasid al-Shariah is then divided into three categories namely; basic interests (al-Daruriyyat), ordinary needs (alHajiyyat) and luxury needs (al-Tahsiniyyat). For the second aspect, al-Shatibi explained that the Shariah created by Allah is to be understood and then to be implemented by human beings. This is because, if the Shariah can't be understood by human beings, then the Shariah created and revealed by Allah doesn't bring meaning to human beings. He presented evidence on this matter by looking at the fact of the decline of the Quran revealed in Arabic. The third aspect is about the purpose of God creating Shariah to be implemented. Humans are responsible for practicing what has been revealed and this implementation is in accordance with human ability itself. Al-Shatibi explained that there is no responsibility (taklif) beyond human ability and this can be proven through Islamic law which always gives flexibility and avoids hardship (al-Haraj) to human beings. The fourth aspect, is the purpose of Allah to place mukallaf under Islamic law. Islamic law is comprehensive in nature which includes syahadah and the supernatural. The purpose of Allah placing mukallaf under shariah law is to prevent human beings from following their lusts and eventually to become servants of Allah voluntarily (al-Shatibi, 2006: 489; al-Raysuni, 1991).

For the division of the second maqasid al-Shariah, which is maqasid al-Mukallaf, al-Shatibi argued that maqasid aims to distinguish between custom and worship and every act of mukallaf is dependent on al-Ahkam al-Taklifiyyah. Therefore, the mukallaf needs to know some basics so that all actions are in line with the maqasid al-Shariah. There are two principles outlined, namely qasd al-Mukallaf (purpose of mukallaf) is in line with qasd al-Shari'ah (purpose of Shariah) and committing acts that violate the purpose of Shariah will lead to the destruction of the essence of qasd al-Mukallaf. Based on these two policies, it can be concluded that Islamic law has set the objective of mukallaf in implementing a prescribed law. The objective of this mukallaf will determine the validity of the Shariah practiced by the mukallaf. In other words, it becomes a measure of whether the practice is considered as a form of devotion to Allah and also a separator to the nature of a believer's faith in Allah or not (al-Shatibi, 2006: 490; al-Raysuni, 1991).

Al-Shatibi also divides the maqasid al-shariah into three levels of human interest, namely daruriyyat (basic needs), hajiyyat (normal needs) and tahsiniyyat (perfection). The first stage is the maqasid al-Daruriyyat. Maqasid al-Daruriyyat is a foundation that is very necessary to achieve the goal of life (maslahah) in this world and the hereafter. If this maqasid doesn't exist, then life in this world and the hereafter will perish and be difficult. The basic things that need to be given priority consist of five basic things, namely religion, life, intellect, lineage and property. The second stage is the maqasid al-Hajiyyat, which is the objective or purpose 
needed to gain space in life and eliminate the narrowness that usually leads to hardship. If this maqasid doesn't exist, then many difficulties to be faced. Even so, it does not reach the point of destroying the system of life or the problems of human life. Ahmad al-Raysuni stated that the goal of al-Hajiyyat is to eliminate difficulties and narrowness in life, protect basic needs, help achieve al-Daruriyyat objectives and ensure the achievement of other needs. If this maqasid al-Hajiyyat is ignored continuously, then it will lead to the eradication of alDaruriyyat. The third stage is maqasid al-Tahsiniyyat, which is to do a good and praiseworthy practice or custom and stay away from things that are considered bad by the perfect intellect. At this stage, this maslahah is not a basic interest or need, rather it is merely an addition to perfection. Maqasid al-Tahsiniyyat is important to help and accommodate in the effort to achieve al-Hajiyyat and al-Daruriyyat. This maqasid is also a maslahah needed to increase human convenience and pleasure (al-Raysuni, 1999).

In addition, al-Shatibi also outlined two basic concepts, namely maslahah and mafsadah in the discussion of the theory of maqasid al-shariah. This is because the main purpose of this shariah is to ensure the welfare and avoid damage (mafsadah) to human beings. Maslahah that should be given priority is to take care of religion, life, intellect, property and lineage. Therefore, there is no law imposed by Allah on human beings that is not intended for the benefit of human beings because all the things prescribed are created in order to realize the welfare of His servants. Therefore, it is important to examine the theory of maslahah because it is the basis of Shariah texts. Al-Shatibi's view was also supported by several other scholars' such as Fathi al-Duryani and Muhammad Abu Zuhrah who said that Islamic laws were not created for the laws themselves, but were created for the benefit of human beings.

\section{The Theory of Maqasid Al-Shariah According to 'Izz Al-Din Ibn 'Abd Al-Salam}

'Izz al-Din ibn 'Abd al-Salam's thought about maqasid al-Shariah is based on two main concepts, namely upholding the good and avoiding the bad things (jalb al-Masalih wa dar ilMafasid) (al-Hasan, 2000). According to 'Izz al-Din ibn 'Abd al-Salam, in understanding Shariah as a whole, one needs to look at the arguments from the Quran and Sunnah to understand the purpose or objective of the Shariah revealed, which is based on the concept of upholding goodness and avoid disadvantages. Next, one must also examine the meaning of the text by looking at the reason ( $i l l a h$ ) that will give the result of the objective of the Islamic law, namely maqasid al-Shariah. Shariah objectives must also be seen in depth and not just externally. He also uses various contents in defining maslahah, including al-Hasan, an-Naf'u and al-Hasanat. Maslahah recognized by Islamic law is maslahah al-Mu'tabarah, which is maslahah that coincides with the requirements of Shariah. 'Izz al-Din ibn 'Abd al-Salam has outlined two characteristics of maslahah recognized by Islamic law, namely that maslahah must be included in the maqasid al-Shariah and don't neglect the maslahah that is more important or similar to it. The objective of maqasid al-Shariah is to safeguard the welfare of human beings by preserving the five basic things, namely religion, life, intellect, property and lineage. Therefore, every act of mukallaf that is not contrary to Shariah is considered as maslahah because the act aims to ensure the welfare of human beings and the maslahah is determined by Islamic law. If there is a clash between maslahah, then the main maslahah should be given priority; namely maslahah al-Daruriyyat, maslahah al-Hajiyyat and maslahah al-Tahsiniyyat. Meanwhile, if there is a clash between public and special interests, then maslahah al-'Ammah must be given priority over maslahah al-Khassah ('al-Salam, 1996 \& 'Abd al-Salam, 1998). 'Izz al-Din ibn 'Abd al-Salam has divided the maslahah, into three main categories, namely alDaruriyyat, al-Hajiyyat and al-Tahsiniyyat. Al-Daruriyyat is the main need that must be 
implemented to ensure religious benefit and the benefits of life in the world. If these basic needs don't exist, then the benefits of life in the world will be lost and damage will occur in human life. This need is also referred to as al-Kulliyat al-Khams, which is to take care of religion, life, intellect, property and lineage. 'Izz al-Din ibn 'Abd al-Salam has added al-'Ird (maintaining dignity) to these five things and mentions them in the book Qawa'id al-Ahkam fi Masalih al-Anam. Al-Hajiyyat is an intermediary between al-Daruriyyat and al-Tahsiniyyat and this includes benefits in this world and the hereafter which aims to make it easier for people to manage life more comfortably. Meanwhile, al-Tahsiniyyat is the highest level which aims to achieve perfection and comfort at the highest level. For example, al-Tahsiniyyat related to the benefit of the world is the perfection of life like having a home that is spacious, comfortable vehicles and others. The benefit of the hereafter is to perform the voluntarily prayers after performing the obligatory prayers. 'Izz al-Din ibn 'Abd al-Salam also explained that these three stages have included safeguarding the benefit of human beings, namely as servants of Allah in general and specifically ('Abd al-Salam, 1996; 'Abd al-Salam, 1998).

In addition, 'Izz al-Din ibn 'Abd al-Salam also discussed the concept of mafsadah in general. According to him, mafsadah is an evil that consists of ugliness, sadness and its causes. He also uses various terms to describe mafsadah, including al-Munkar, al-Qabih, as-Syarr and asSaiiyiat. The concept of mafsadah aims to warn people about the consequences of bad deeds and ask people to stay away from them. Mafsadah is divided into two divisions, namely major sins and minor sins. 'Izz al-Din ibn 'Abd al-Salam defines a great sin as an offense committed by human beings in relation to the harm and this sin is different according to the degree of the offense committed. Among the major sins are seven things, namely worshiping a god other than Allah, killing, qazaf, eating the property of orphans, practicing riba, running away from the battlefield and leaving the Islamic state after migrating. Minor sin refers to every word and deed that is not restricted and not punished in the hereafter such as deceiving people and the deception does not cause harm. In this context, minor sins lead to less damage than major sins. Minor sins depend on the small or great evil done. However, a person can be convicted of a major sin if he commits minor sins in an extreme way (Umar, 2003).

As for the maqasid mukallaf, 'Izz al-Din ibn 'Abd al-Salam did not discuss it in detail, but he set four conditions of mukallaf in maqasid al-Shariah. Firstly, the action and purpose of mukallaf in accordance with the maqasid al-Shariah and this causes the result of the maqsad with the erection of maslahah and avoid mafsadah outwardly and inwardly. Secondly, the actions and purposes of mukallaf which contradicts the maqasid al-Shariah such as the mukallaf abandoning the commands of Allah and doing the prohibitions of Allah. Thirdly, the purpose (qasad) of mukallaf which coincides with Islamic law, but its actions violate the maqasid al-Shariah. 'Izz al-Din ibn 'Abd al-Salam mentioned that this act of mukallaf is not sinful, instead it is forgiven because it is thought that mukallaf brings maslahah. The last thing is the purpose of mukallaf which is contrary to Islamic law, but its action is good, which is to follow the maqasid al-Shariah. In this situation, the act of mukallaf is punished as a wicked person and can not be a witness in various matters because in fact, it is contrary to the maqasid al-Shariah and does not comply with the requirements of Islamic law ('Umar, 2003).

\section{Comparative Analysis of Maqasid Al-Shariah Theory by Al-Shatibi and 'Izz Al-Din Ibn 'Abd} Al-Salam

In the discussion on the maqasid al-Shariah, al-Shatibi has divided the maqasid into two important parts, namely the maqasid al-Shari' and maqasid al-Mukallaf. In terms of qasd alShari', he has divided it into four important features namely; the purpose of Allah to create 
Shariah itself, the purpose of Allah to create Shariah to be understood, the purpose of Allah to make Shariah to be practiced and the purpose of Allah SWT to place mukallaf under Shariah law. However, al-Shatibi was not the first to discuss qasd al-Shari', instead al-Juwayni (478H) better known as Imam Haramayn gave his views on maqasid al-Shariah as a matter with universal value. In a discussion on qasd al-Mukallaf, al-Shatibi mentions in his book, alMuwafaqat that the mukallaf (man) who commits an act or who leaves it is judged whether his act is in accordance with the maqasid al-Shariah or vice versa. Al-Shatibi has elaborated on this debate and he divided it into four elements, namely his action and purpose in accordance with the maqasid al-Shariah, his action and purpose contradict the maqasid alShariah, the act of mukallaf coincides with the law of Shariah, but its purpose contradicts the maqasid al-Shariah and the act of mukallaf is contrary to Shariah, but the purpose is good. Izz al-Din ibn 'Abd al-Salam also discusses the maqasid al-Mukallaf indirectly in his book, Qawa'id al-Ahkam fi Masalih al-Anam. He explained the elements that need to be complied with by the mukallaf by upholding maslahah and avoiding mafsadah in order to ensure benefit in the hereafter and the main purpose is to gain the pleasure of Allah. 'Izz al-Din ibn 'Abd al-Salam in giving his views on the maqasid al-Shariah, has discussed it based on the concept of maslahah and mafsadah, which are twin concepts that are related to each other. The discussion of maslahah and mafsadah on the side of 'Izz al-Din ibn 'Abd al-Salam refers to the maqasid al-Shariah in two concepts, namely the world and the hereafter. The same thing was also outlined by al-Shatibi, that maslahah and mafsadah are divided into two parts, namely worldly matters and the hereafter. 'Izz al-Din ibn 'Abd al-Salam discussed mafsadah and stated that small sins and major sins should be avoided in order to achieve maslahah (goodness). Figure 1.1 is the illustration of the divison of maqasid al-Shariah according to alshatibi \& 'Izz al-din ibn 'Abd al-Salam. Whereas, Figure 1.2 is the illustration of maslahah and mafsadah from the perspective of priorities according to Al-Shatibi AND 'Izz Al-Din Ibn 'Abd al-Salam.

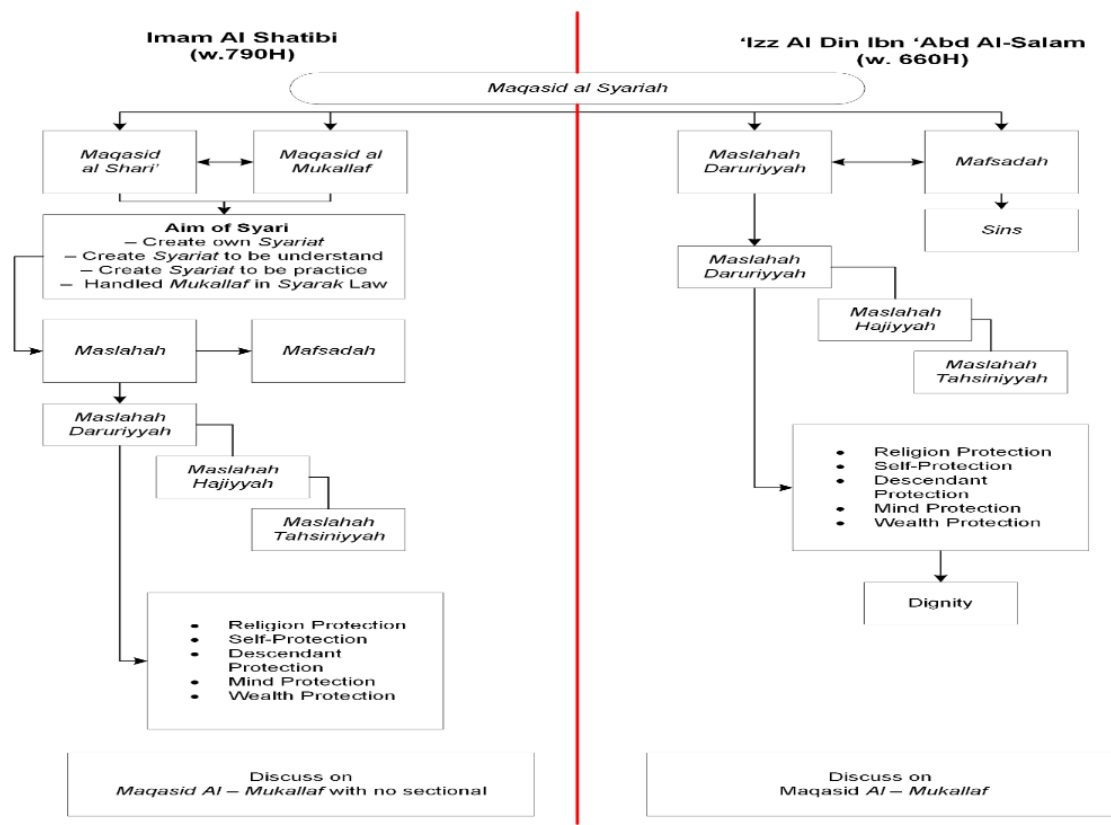

Figure 1.1: The Divison of Maqasid al-Shariah According to Al-Shatibi \& 'Izz al-din ibn 'Abd al-Salam. 


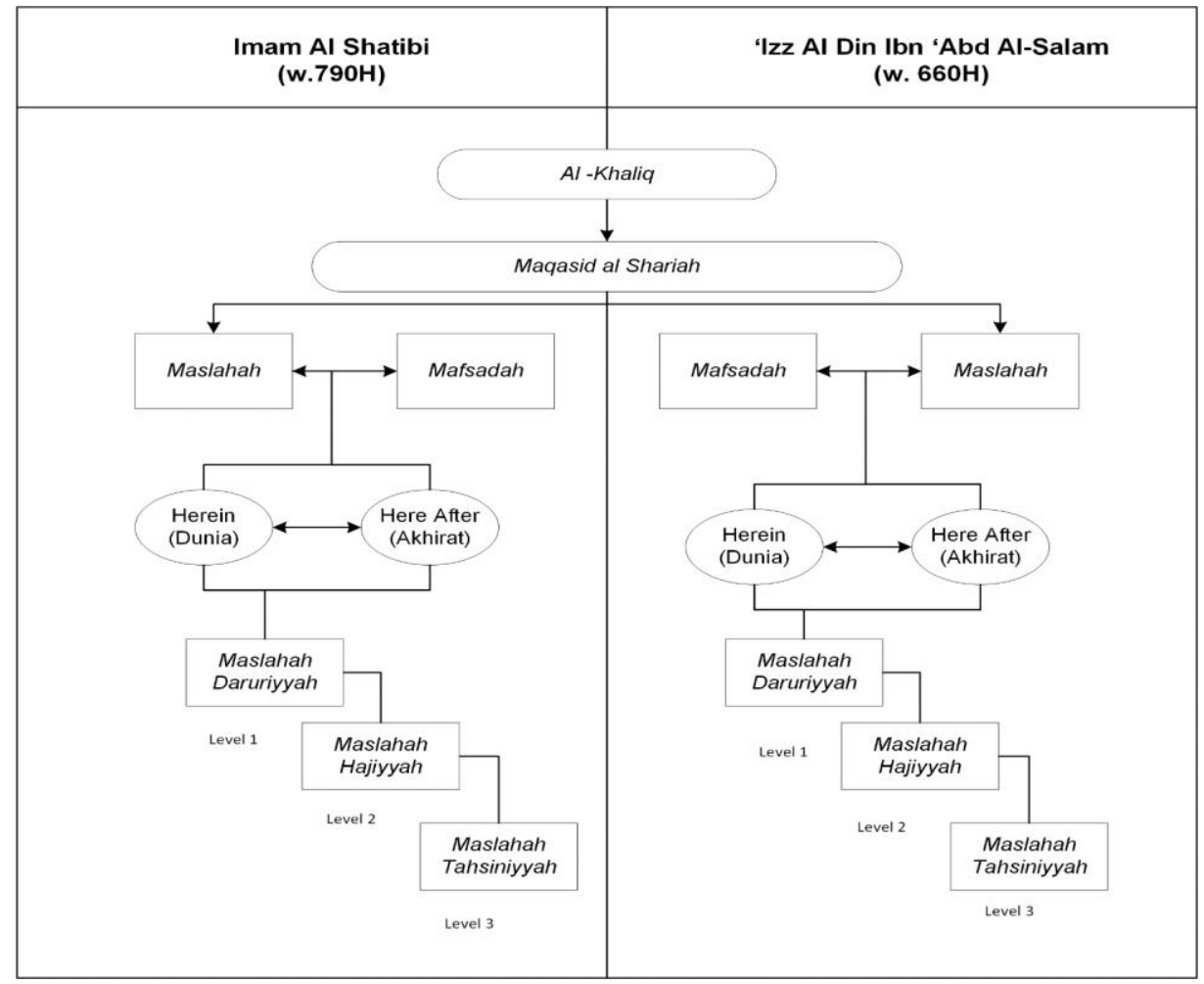

Figure 1.2: Maslahah and Mafsadah from the Perspective of Priorities According to AlShatibi And 'Izz al-Din Ibn 'Abd al-Salam

There are several concepts that underlie and move in line with the maqasid al-Shariah. Among them is the concept of darurah which is more applied in al-Darurriyyat al-Khams. The law of al-Taklifi is prescribed for the purpose of maintaining the maqasid al-Shariah, which is the purpose of its legislation. Maqasid al-Shariah in terms of the strength of application, its importance and priority are divided into three parts, namely; al-Daruriryyat (basic needs and necessities), al-Hajiyyat (additional needs) and al-Tahsiniyyat (perfection). Al-Shatibi and 'Izz al-Din ibn 'Abd al-Salam discussed about al-Darurriyyat al-Khams in their work, al-Muwafaqat and Qawa'id al-Ahkam fi Masalih al-Anam. Both figures have made a division of al-Darurriyyat al-Khams as maslahah that should be given priority first. The first scholar who propagated the priority of these five basic things was Abu Hamid al-Ghazali who relied on the Five Key Things (al-Daruriyyat al-Khams) in the care of darurah, namely the preservation of religion, life, intellect, lineage and property. Meanwhile, scholars in the field of usul al-Fiqh that emerged later quoted and accepted them well until the doctrine is famous to this day. The care of the five interests has been agreed upon among the scholars, although there are differences in terms of number and items. Al-Shatibi mentioned in al-Muwafaqat by placing priority, which is to take care of religion, self, lineage, property and intellect. In his other book, al-I'tisam, he mentioned the priority, which is to take care of religion, self, lineage, intellect and property. In this case, al-Shatibi didn't add any items other than what was stated by Imam al-Ghazali. Meanwhile, 'Izz al-Din ibn 'Abd al-Salam mentions al-'Ird (maintaining dignity), in his book, Qawa'id al-Ahkam fi Masalih al-Anam. However, 'Izz al-Din ibn 'Abd al-Salam didn't state his priorities clearly even though he mentioned the preservation of religion, lineage, dignity, property and intellect. Most scholars in the field of usul al-Figh, among them Imam al-Ghazali showed five main things, namely al-Darurriyyat al-Khams to take care of five things namely; religion, life, intellect, lineage and property. Nonetheless, al-Amidi also mentioned five priorities, namely to protect religion, life, lineage, intellect and property. In placing the 
sequence, he prioritizes lineage over intellect different from Imam al-Ghazali who prioritizes intellect over lineage. Although scholars in the field of usul al-Fiqh set their priorities differently, but scholars, including al-Shatibi and 'Izz al-Din ibn 'Abd al-Salam agreed that the five interests should be given priority for the benefit of mankind. Figure 1.3 is the diagram of the five necessities (al-Daruriyyat al-Khams) according to al-Shatibi and 'Izz al-Din ibn 'Abd alSalam.

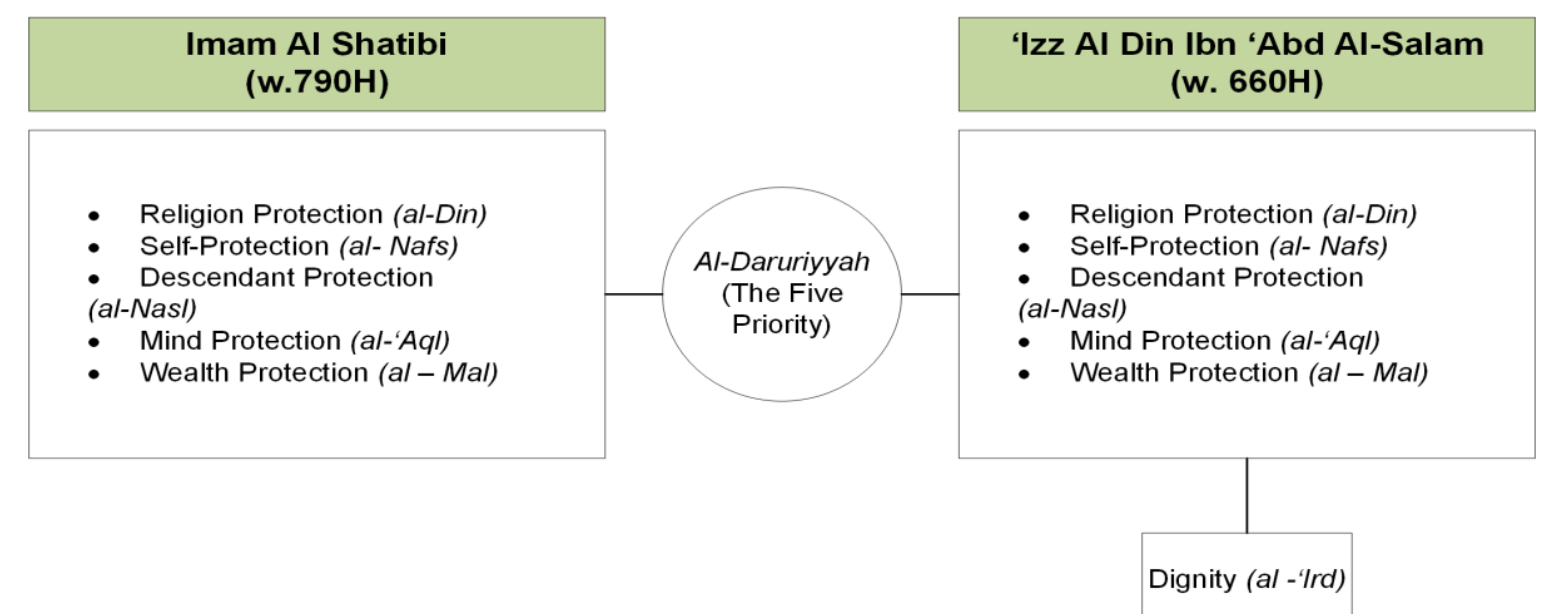

Figure 1.3: The Five Necessities (Al-Daruriyyat Al-Khams) According to Al-Shatibi and 'Izz AlDin Ibn 'Abd Salam

In terms of terminology, previous scholars in usul al-Fiqh have used the term ta'lil al-Ahkam. In the science of fiqh, the study of Islamic laws is an attempt to know the secret behind each law or better known as masalik al-Hukm. According to al-Shatibi, Islamic law is mu'allalah (cause). Every law revealed has a cause and has a specific purpose. The relationship between the deeds and the laws of Allah SWT has 'illah. The law of Allah was created based on the benefit of human beings in this world and in the hereafter. Similarly, 'Izz al-Din ibn 'Abd alstated that the purpose of the law of Allah is for the benefit of human beings in this world and the hereafter. In the discussion of this problem, previous scholars also argued that Islamic law has to do with 'illah, hikmah and maslahah. This opinion was pioneered by the Salaf, mostly followers of the four sects. The concept of ta'lil al-Ahkam encompasses the purpose and objective of Islamic law, namely the achievement of maslahah in the context of human happiness in this world and in the hereafter. This concept was certainly agreed upon by scholars in usul al-Fiqh, including al-Shatibi and 'Izz al-Din ibn 'Abd al-Salam.

One of the discussions in the science of maqasid al-Shariah is how to identify maqasid alShariah from the scholars' perspectives. Relatively speaking, there are three groups that set the basics for identifying the maqasid al-Shariah. The first group is al-Zahiriyyah scholars (Bakri, 1996: 90) who think that knowing the maqasid al-Shariah is only directly through the zahir nas (external text). The second group argues that maqasid al-Shariah only through the meaning behind the zahir nas and this group is referred to as al-Batiniyyah scholars. While the third group is the group who use the nas (revealation) approach either outwardly and also see the ta'lil al-Ahkam that results from the nas. This group is mostly from scholars of Usul Wa Ahli Jamaah or known as al-Rashikin (Bakri, 1996). Between these two figures, there are some similarities and differences that are shared in identifying the maqasid al-Shariah. First, the two figures agree that the text of the Quran and Sunnah is the most important way of recognizing the maqasid al-Shariah (al-Shatibi, 2006). 'Izz al-Din ibn' Abd al-Salam used terms 
such as shara', al-Naql and al-Kitab when discussing the main sources in his analysis of the maqasid al-Shariah ('Abd al-Salam, 1998; 'Umar, 2003). Al-Shatibi explained that there are several forms that need to be understood, namely to do an analysis of the text in the form of command (al-Amr) and prohibition (an-Nahi), research on 'illah al-Amr (command) and analysis of the attitude of silence al-Shari' from the provision of something (Bakri, 1996). It is clear and understandable that al-Shatibi refines the ways of identifying the maqasid alShariah by examining in depth the texts of the Shariah (al-Shatibi, 2006; al-Raysuni, 1991). It aims to achieve the level and true meaning of the text of the Quran and Sunnah so that it is in line with the will of the creator (Allah SWT) and the purpose of the Shariah (al-Shatibi, 2006).

According to al-Shatibi, in order to achieve a broad scope of understanding of maqasid alShariah, it is not limited to examine the pronunciation of the command (al-Amr) and the prohibition (an-Nahi) only. In fact, he emphasized on ta'lil al-Ahkam that needs to be investigated and identified in order to achieve the real objective. In addition, al-Shatibi also asserts that the evaluation of the secondary objective (al-Maqasid al-Tab'iyyah) which is the basis of the original objective (al-Maqasid al-Asliyyah). The second objective is referred to as qasd al-Thani which aims to perfect the goal in reverse (al-Shatibi, 2006; al-Raysuni, 1991). 'Izz al-Din ibn' Abd al-Salam also suggested that it is necessary to understand the wording of the commandments and prohibitions in the texts. But it is more towards the understanding of the wording of the command that brings maslahah and the wording of the prohibition to reject mafsadah ('Abd al-Salam, 1998). For example, the command to pray and give zakat will bring good in this world and in the hereafter, while the prohibition of drinking alcohol and eating the property of orphans is to reject mafsadah, in other words, it also aims to bring maslahah when not doing things that are forbidden. According to 'Izz al-Din ibn' Abd al-Salam, the text that is targhib, is to explain maslahah and the text that is in the form of tarhib is to explain mafsadah. Al-Amidi states that the habit of uttering instructions is to produce maslahah and uttering prohibitions is to reject mafsadah ('Abd al-Salam, 1998: 187).

'Izz al-Din ibn 'Abd al-Salam applied the concept of istiqra' (inductive) in identifying the maqasid al-Shariah. He repeatedly used this concept in making research and understanding of maslahah and mafsadah (Umar, 2003). In contrast to al-Shatibi who didn't clearly state the use of istiqra', Ahmad al-Raysuni stated that al-Shatibi didn't mention the use of istiqra' when describing in the chapter the ways of identifying the maqasid of al-Shariah. Al-Raysuni commented on the question of istiqra' and mentioned that if the level of importance of the use of istiqra' to identify the maqasid al-Shariah is observed, it indicated that this is very important even though al-Shatibi doesn't mention about its usage (al-Raysuni, 1991). Although al-Shatibi doesn't mention its usage explicitly, al-Raysuni argues that al-Shatibi also uses the concept of istiqra'. Al-Raysuni's opinion is based on some of al-Shatibi's views on several issues and it can be seen that al-Shatibi uses istiqra' indirectly even though he doesn't explicitly mention in the debate the ways of identifying the maqasid of al-Shariah.

There are similarities about the use of tajribah (experiment) as one of the methods of identifying the maqasid al-Shariah. 'Izz al-Din ibn' Abd al-Salam used this method in recognizing maslahah and mafsadah 'Abd al-Salam, 1998). While the use of tajribah in knowing this maslahah is followed by al-Shatibi, as stated by 'Izz al-Din ibn 'Abd al-Salam in his book Al-Muwafaqat Fi Usul al-Shariah. Al-Shatibi applied tajribah in taking care of worldly maslahah and 'Izz al-Din ibn 'Abd al-Salam also applied tajribah either in worldly maslahah and its causes, as well as in the question of mafsadah and its causes. From the point of view of the use of the intellect ('aql), 'Izz al-Din ibn 'Abd al-Salam asserted that the intellect is one 
of the ways to know things related to the problems of the world and hereafter that are only through the text (nas). In this case he put dawabit (procedure) as a guidance so that the intellect used is not followed by merely lust. He stressed that it becomes a necessity to make observations because observation leads to the knowledge of something ('Umar, 2003). Meanwhile, al-Shatibi mentioned that if the intellect and the text collide in the matter of the Shariah, the text should be given priority over the intellect (al-Shatibi, 2006). Based on this discussion, it can be understood that there is no significant difference between al-Shatibi and 'Izz al-Din ibn 'Abd al-Salam regarding the means of identifying and understanding the maqasid al-Shariah. Al-Shatibi further refines the ways to understand the maqasid al-Shariah to be better understood as best as possible. It is clear that knowing the ways to know the maqasid al-Shariah is very important, especially for researchers of Islamic law. Table 1.2 below is the differences between these two figures in identifying maqasid al-Shariah:

\begin{tabular}{|c|c|}
\hline Al-Shatibi (790H) & ‘Izz Al-Din Ibn ‘Abd Al-Salam (660 H) \\
\hline $\begin{array}{l}\text { - Quran and Sunnah are the most } \\
\text { important ways of recognizing } \\
\text { maqasid al-Shariah. }\end{array}$ & $\begin{array}{l}\text { - Quran and Sunnah is the main ways } \\
\text { of recognizing the maqasid al- } \\
\text { Shariah. }\end{array}$ \\
\hline $\begin{array}{l}\text { - He has emphasized ways of } \\
\text { recognizing maqasid al-Shariah into } \\
3 \text { parts: } \\
\text { 1. To analyse the command (al- } \\
\text { Amr) and prohibition (al-Nahi) } \\
\text { texts. } \\
\text { 2. To observe the 'illah of al-Amr } \\
\text { (the cause of the command) } \\
\text { 3. To analyse the silence behaviour } \\
\text { of shara' in related matters }\end{array}$ & $\begin{array}{l}\text { - Need to understand the wording of } \\
\text { the command and prohibition (al- } \\
\text { Amr \& al-Nahi) in texts. It's more } \\
\text { focused to the understanding of the } \\
\text { wording of the command which } \\
\text { brings maslahah and the prohibition } \\
\text { to eliminate mafsadah. }\end{array}$ \\
\hline $\begin{array}{l}\text { - Didn't mentioned about the istiqra' } \\
\text { (inductive) method in identifying } \\
\text { maqasid al-Shariah. }\end{array}$ & $\begin{array}{l}\text { - Used the istiqra' (inductive) method } \\
\text { in identifying maqasid al-Shariah } \\
\text { that refers to the concept of } \\
\text { maslahah and mafsadah. }\end{array}$ \\
\hline $\begin{array}{l}\text { - Using al-Tajribah (experiment) in } \\
\text { identifying maqasid al-Shariah. }\end{array}$ & $\begin{array}{l}\text { - Using al-Tajribah (experiment) in } \\
\text { identifying maqasid al-Shariah. }\end{array}$ \\
\hline $\begin{array}{l}\text { Prioritize the text (nas) over the } \\
\text { intellect ('aql) in worldly and } \\
\text { hereafter matters; can be known } \\
\text { through Islamic texts. }\end{array}$ & $\begin{array}{l}\text { - Used intellect ('aql) to identify the } \\
\text { maqasid al-Shariah in worldly } \\
\text { matters, while the matters related to } \\
\text { hereafter can be known through the } \\
\text { text of shara'. }\end{array}$ \\
\hline
\end{tabular}

Table 1.2: How to Identify Maqasid al-Shariah According to Al-Shatibi and 'Izz Al-Din ibn 'Abd Al-Salam

\section{Conclusion}

In a nutshell, it can be concluded that there is no significant difference between both figures about the theory of maqasid al-Shariah. In fact, the topic of discussion on the theory of maqasid al-Shariah by both figures is related to each other. What differentiates between them is the form and approach in dealing with the maqasid al-Shariah. 'Izz al-Din ibn 'Abd al- 
Salam presented the theory of maqasid al-Shariah which is based on the concept of maslahah and mafsadah. Meanwhile, al-Shatibi refers to the objective of the creator, namely qasd alShari' in discussing the maqasid al-Shariah. In addition, maqasid al-Shariah has become an important element in the effort to understand Islamic law of jurisprudence. Islamic law should not be understood only from the scope of the text alone, but should also consider the objective why the law is set in the text of the Quran and Sunnah.

\section{References}

Ali, A. R. (1998). Al-Imam al-Syatibi 'Aqidatuhu wa Mawqifuhu min al-Bid'i wa Ahliha. Riyadh: Maktabah al-Rushd li Nasyar wa Tauzi'.

Al-Din al-Subki, A.D (n.d). Tabaqat al-Syafi'yyah al-Kubra. Jil. 8. Qahirah: Taba'ah 'Isa al- Bab al-Halabi.

Adil, B. (1983). Mu'jam al-Mufassirin: Min Sadr al-Islam hatta al-'Asr al-Hadir. Vol. 2. Mu'assasah Nuwayhid as-Saqafiyah.

Ali, J., \& Al-Hasan, A. M. (1971). Ma'a al-Qa'id al-Ruhi li al-Sya'bi: Sultan 'Ulama' al-Imam al'Izz ibn 'Abd al-Salam. Qahirah: Maktabah al-Anjelu al-Masriyyah.

Al-Shatibi, A. I. I. (1996). Al-Ifadat wa al-Insyadat. Kaherah: Dar al-Hadith.

Al-Shatibi, A. I. I. (2006). Al-Muwafaqat fi Usul al-Shari'ah. Vol. 2. Kaherah: Dar al-Hadith.

Isma'il, A. S. A. R. (1945). Al-Zayl 'ala Rawdatayn. Beirut: Dar al-Jayl.

Baba, A. (1989). Nayl al-Ibtihaj. Tahqiq 'Abd al-Hamid 'Abd Allah al-Haramah. Tarabalas: Kuliyyah Da'wah al-Islamiyyah.

Al-Raysuni, A. (1992). Nazariyat 'Inda Imam al-Syatibi. Riyadh: Dar al-'Alamiyyah.

Al-Raysuni, A. (1999). Al-Fikr al-Maqasidi Qawa'id wa Fawa'id. Casablanca: Al-Najah alJadidah.

Bakri, A. J. (1996) Konsep Maqasid Syariah Menurut al-Shatibi. Jakarta: PT Raja Grafindo Persada.

Jasser, A. (2007). Fiqh al-Maqasid Inasat al-Ahkam bi Maqasidiha. Herndon: IIIT.

Gali, A. B. (1996). Syaikh al-Jami' al-A'zam Muhammad at-Tahir ibn 'Asyur: Hayatuh wa Asaruh. Beirut: Dar Ibn Hazm.

'Alal, A. F. (1993). Maqasid al-Syari'ah al-Islamiyyah wa Makarimuha. Ribat: Dar al-Gharb alIslami.

Ismail, A. H. (1995). Nadzariyat al-Maqasid 'Inda al-Imam Muhammad at-Thahir bin 'Asyur. Kaherah: Al-Ma'had al-'Alami li al-fikr al-Islami.

Al-'Ubaydi, H. (1992). Al-Syatibi wa Maqasid al-Syari'ah. Beirut: Dar Qutaybah.

Tahir, A. (2001). Maqasid al-Syari'ah. Jordan: Dar al-Nafais.

Yusuf, Al-M. J. A. D. (t.t). Al-Nujum al-Zahirah Fi Muluk Masr wa al-Qahirah. Vol. 7. Qahirah: Mua'sasah al-Masriyyah.

Al-Zarkali, K. A. D. (1987). Al-A'lam. Jil. 1. Beirut: Dar al-'Ilm li al-Malayin.

Al-Hasan, K. B. (2000). Falsafah Maqasid al-Tasyriffi al-Figh al-Islami. Qahirah: Maktabah Wahbah.

Syalabi, M. (1992). Hayah Sultan 'Ulama' al-'Izz ibn 'Abd al-Salam. Beirut: Dar al-Jayl.

Abu al-Ajfan, M. (1985). Fatawa Imam al-Syatibi. Tunisia: Matba'ah al-Kawakib.

Masud, M. K. (1995). Syatibi's Philosophy of Islamic Law. Kuala Lumpur: Percetakan Zafar Sdn.Bhd.

Muhammad, M., \& 'Asyur, M. (2002). Al-Thabit wa al-Mutaghayyar fi Fikr al-Imam Abi Ishaq al-Shatibi. Dubai: Dar al-Buhuth li Dirasat al-Islamiyyah wa Ihya' al-Turath. 
Berkani, O. (1999). Al-ljtihad al-Maqasidi 'Inda 'Izz al-Din ibn 'Abd al-Salam. Master Theses, Kuliyyah Ma'arif al-Wahyu wa al-'Ulum al-Insaniyyah. Universiti Islam Antarabangsa Malaysia.

Subuie, S. (1999). Al-Fikr al-Lughawi 'Inda al-Syatibi, Dirasah Tahliliyyah Tatbiqiyyah Fi Lughah al-'Arabiyyah. Master Theses, Kuliyyah al-Ma'arif al-Wahyu al-'Ulum al-Insaniyyah, Universiti Islam Antarabangsa Malaysia.

Ali, S. R. (t.t). Izz al-Din al-Sulami : His Life and Works. Islamabad: Islamic Research Institute.

Gazi, A.T. (2008). Limaza Saqatat ad-Dawlah al-'Usmaniyyah: Qira'ah fi 'Awamil Da'f alUmmah. Beirut: al-Maktab al-Islami.

Qahalah, U. R. (t.t). Mu'jam al-Mu'allifin Tarajim al-Musannafi al-Kutub al-'Arabiah Vol.1. Beirut: Dar al-Ihya' al-Turath al-'Arabi.

'Umar, S. (2003). Maqasid al-Syari'ah 'Inda al-Imam 'Izz al-Din 'Abd al-Salam. Jordan: Dar al-Nafais. 